\author{
Ryszard Pukala, \\ Ph.D., Vice-Rector for Student Affairs, \\ State Higher School of Technology and Economics in Jaroslaw, \\ Jaroslaw, Poland \\ Elena Sira, \\ Ph.D., Department of Economics and Economy, \\ University of Presov in Presov, \\ Presov, Slovakia \\ Roman Vavrek, \\ Ph.D., Department of Management, \\ University of Presov in Presov \\ Presov, Slovakia
}

\title{
RISK MANAGEMENT AND FINANCING AMONG START-UPS
}

This article is a part of a multi-layered scientific discussion dedicated to risk management methods and their efficiency as well as the use of risk financing instruments available on the market by start-ups. The authors have to emphasize that due to their specific business activity, these entities do not fit into traditional statistics, so it is very hard to analyse this environment without targeted research. What is more, due to a relatively short history of start-ups in the realm of global economy, we lack a broader spectrum of publications that would present results of studies and analyses devoted to the activity of such innovative enterprises. This study attempts at filling this gap and takes on the theme that has not been investigated so far, despite its topicality resulting from the growing significance of start-ups in the economy, not only on the national but also on the international scale. The main objective of the study is to learn about the use of risk management tools and methods of risk financing in this group of entities. Research tools used in the analysis included questionnaires and expert opinions gathered in the course of conducting in-depth interviews. The expert synthesis was carried out by means of a multi-criterion Analytic Hierarchy Process, used at analysing complex decision-making problems. The study focused on 25 start-ups incubated at the Podkarpacki Science and Technology Park, which is located in the south-eastern region of Poland. The research group was gathered on the basis of targeted selection, so as to take account of the specificity of such enterprises. A group of 10 experts took part in the research. They represented start-ups, financial and scientific sectors and were knowledgeable in the field of start-up activity. The article presents results of an empirical analysis, which demonstrated that start-ups did not use risk management tools in their business activity, accepting risk mainly as self-insured retentions and treating it as an indispensable element of their activity without making any minimizing attempts. The study also showed that insurance was the best risk financing instrument for this group of entities. The obtained results can contribute to further multilayered studies in the scope of start-up activity subject to volatile business risk and can be used in practice by such entities in the process of limiting their business risk.

Keywords: start-up, risk, risk management, risk financing, insurance.

Introduction. Contemporary enterprises, acting in highly competitive and changing market surroundings, constantly seek new business solutions that could contribute to their rapid development and gaining competitive advantage. Their development, often based on new and unique technologies, contributes to providing durable and sustainable economic development and is a vector for the development of the entire economy. This is also reflected in gradually increasing expenditure aimed at 
stimulating the development of innovation and commercialization of effects of research and development work and incurred both by particular countries and on the global scale. These outlay contribute to creating novel solutions and increase the innovation level among enterprises.

We can classify start-ups to this group. Through their innovative undertakings aimed at seeking their own unique paths of development, they can quickly dominate domestic and global markets. The term "start-up" is mainly associated with the business world and we can come across multiple definitions thereof. However, we can assume that a common objective of a start-up is to prove that while maintaining a relatively low level of cost involvement it is still possible to put an underlying idea into practice. What is also important is the possibility of operating a business model that determines a method of gaining revenues and the potentiality of success measured in business terms [1]. However, business activity of start-ups is burdened with a high level of risk, which means that this type of enterprises should pay particular attention to risk management tools, apply various risk management practices and use risk management instruments on a broad scale. These solutions would certainly come up as support factors for these enterprises, would allow limiting hazards intrinsic to their operation and could contribute to their achievement of market success.

Literature review. Risk is an integral element of each business activity and has its theoretical and practical definitions used in various fields of science. It is related to the most fundamental aspects of psychology, mathematics, statistics and history. However, it is most frequently related to entrepreneurship, where it is reflected in an enterprise risk theory.

One of the first authors to have attempted at defining risk was A. H. Willet, who declared that risk is something impartial, although related to subjective uncertainty [2]. Frank $\mathrm{H}$. Knight developed the concept of risk [3]. His main aim was to clarify what features the uncertainty identified as a risk should have in comparison to uncertainty in the strict sense. This concept treats risk as measurable uncertainty, whereas uncertainty that cannot be measured is the uncertainty in the strict sense, the one that Knight named nonmeasurable uncertainty. According to W.D. Rowe, the risk is a concept consisting of two main components: an emergence of possible unwanted consequences or losses and uncertainty as regards those consequences, expressed as probability [4]. However, according to the definition coined by L. Tepman, the risk is a possibility of the emergence of an unfavourable situation while implementing plans and executing enterprise budgets [5]. This author underlines that risk is a category that should be conceived as a potentiality of losing resources or failing to obtain income, as compared to a variant that takes account of a rational use of resources in a specified time of conducting business activity.

We need to stress that the concept of risk was addressed by a broad spectrum of researchers, including Nobel Prize laureates, such as, among others: H. Markowitz, F. Black, M. Scholes and R. Merton [6]. We can see that there are numerous aspects of defining risk and mutual relationships that take place between risk and uncertainty [7]. It is also difficult to clearly define the concept of risk, as it is perceived in a different way by representatives of different sciences or areas of business activity and at the same time it is subject to evaluation over time [8-9].

For the purpose of this study, the definition of risk coined by A. Damodaran has been assumed. In his words, risk "is a choice between a greater chance burdened with a higher risk and a smaller chance burdened with a lower risk" [10]. It reflects the nature of risk faced by start-ups and characterizes the essence of start-ups, as it defines them as enterprises that only seek a scalable and repeatable business model that would enable them to stay on the market and continue their development [11]. Here, scalability means a relatively proportional increase in the market share. We can also assume that a start-up is an organisation that creates products and services under conditions of extreme uncertainty [12]. Therefore, a start-up is an enterprise that seeks a business model. The development of this model creates value that allows it to gain profits [13].

When focusing on start-ups, it is worth recalling their specific features that include [14]: 
- no history - these are usually young enterprises that cannot pride themselves in a long business history and many of them have very limited historical financial data;

- low or no income as well as losses on the business operation - limited financial data usually become of little value due to meagre informative content as well as recognising a permanent loss on business operation;

- dependence on foreign capital - in the initial period start-ups usually utilize founders' own funds, EU funds or investors' private funds (venture capital or business angels);

- considerable risk of failure - most young companies cannot succeed in an attempt to introduce a given product on the market and are forced to terminate their operation.

Following this approach, we can assume that start-ups are enterprises that are established in order to implement innovative solutions or products at a relatively low cost. Their main objectives are similar to those shared by most enterprises: making considerable profits and achieving satisfactory benefits for owners or shareholders.

Research goal. The emergence of new, innovative enterprises that include start-ups should currently be treated as a challenge to be stood up to in the context of the development of the Polish economy and efficient competition of newly established enterprises on the European and global market. Their rapid growth and the quickest possible achievement of an optimal business model are the sole guarantee of market success and can become a significant incentive for economic growth. Start-ups belong to high-risk undertakings and thus require particular financial protection against the risk they are exposed to. A broad assortment of risks that influence start-ups adds particular significance to the use of risk management tools.

We have to stress that risk management is a process in which an enterprise solves accompanying risk-related problems in an organised way, so that the operation brings about durable benefits, both in particular areas and considered as a whole [15]. In order for the risk management and financing process to function properly, it should be coupled with other processes taking place at an enterprise, regardless of whether in a small, medium-sized or a large company [16].

Therefore, this study aims at finding out about the approach of start-ups to the issue of risk identification, risk management and how the identification of optimal risk financing instruments that could help them reduce business risk is carried out.

The conducted analyses adopted a proprietary definition of a start-up, according to which it is an innovative organisation without an operational history that looks for a scalable, repeated and profitable business model in the reality of high-risk level and low, often undefined demand, depending on capital sources and characterised by a low survival rate. Additionally, the adopted research hypotheses were verified. According to them:

- $\mathrm{H} 1$ - start-ups use risk management tools on a limited scale;

- H2 - start-ups fail to transfer their risk, which most often remains their self-insured retention;

- $\mathrm{H} 3$ - insurance is an optimal instrument of financing start-up business risk.

Key research findings. When it comes to the execution of objectives put forward in this document, a study was carried out among 25 start-ups, either active within the Podkarpackie Science and Technology Park or acting as independent entities. All analysed enterprises complied with the definition of a start-up adopted for the purpose of the study. The research group was assembled on the basis of targeted selection, so as to take account of the specificity of such enterprises and safeguard their representativeness to the greatest possible extent. Additionally, a group of 10 experts were invited to the research. They represented start-ups, financial and scientific sectors and were knowledgeable in the field of start-up activity.

The research was divided into two steps using different methods. The application of two methods aimed at yielding the most objective research results possible that can at the same time refer to the entire 
population of start-ups operating on the market.

Step I - a survey. A study in the selected group of start-ups was conducted in August 2018 with the use of a survey, the application of which allowed verifying the assumed research hypotheses within the group of analysed entities. It also allowed determining the most general model of behaviour for the group of analysed entities.

The study focused on the key areas related to the start-up business risk and aimed at finding answers to the following questions:

1. How does risk management function in start-ups?

The conducted study unambiguously indicates that risk management in start-ups is applied on a very small scale - see Figure 1 below.

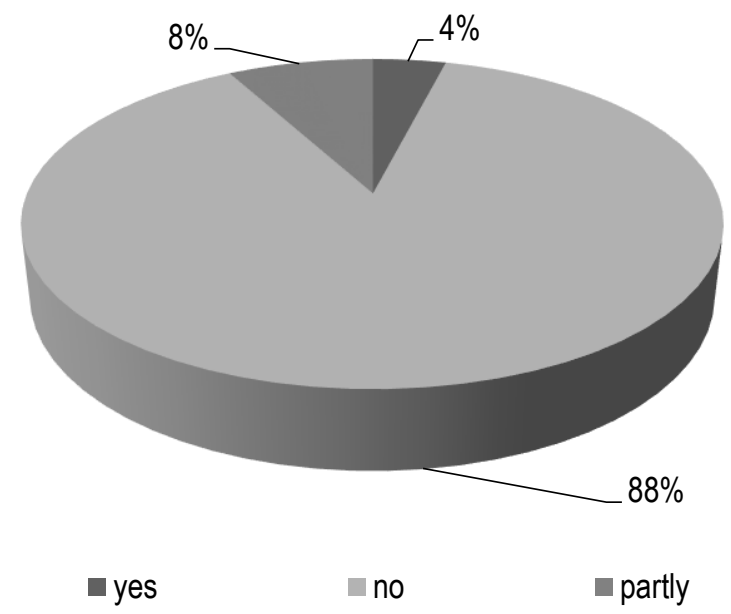

Figure 1 - Is there a risk management system at a start-up? (own study based on conducted analyses)

As many as $96 \%$ of respondents declared that there were no or only partial risk management procedures at the companies (which demonstrates that the $\mathrm{H} 1$ research hypothesis had been positively verified). At the same time, $92 \%$ of respondents stated that all decisions regarding risk management were made by directors and that they were solely responsible for preparing and implementing all procedures in this field. As a result of an analysis of identification data of the studied entities, we could justify the above by the size of the examined enterprises: micro-enterprises employing up to 9 persons and with a relatively short presence on the market - $56 \%$ of them are active for less than 2 years - prevail ( $88 \%$ of respondents). We can conclude on that basis that despite high business risk start-ups do not pay much attention to the implementation and application of risk management tools, which undoubtedly contributes to fossilizing business risk at the same level of intensity. In the light of the above, the study concentrated further on investigating how start-ups deal with risk - question 2.

2. What reactions to risk are preferred by a start-up?

An attitude to risk is a very important aspect of each start-up operation. At the same time, it indicates to what extent an enterprise applies risk management mechanisms and uses risk financing instruments. As indicated by the conducted research (relevant data are presented in Figure 2), start-ups basically refrain from taking action aimed at limiting the risk they face (which demonstrates that the $\mathrm{H} 2$ research hypothesis had been positively verified). 


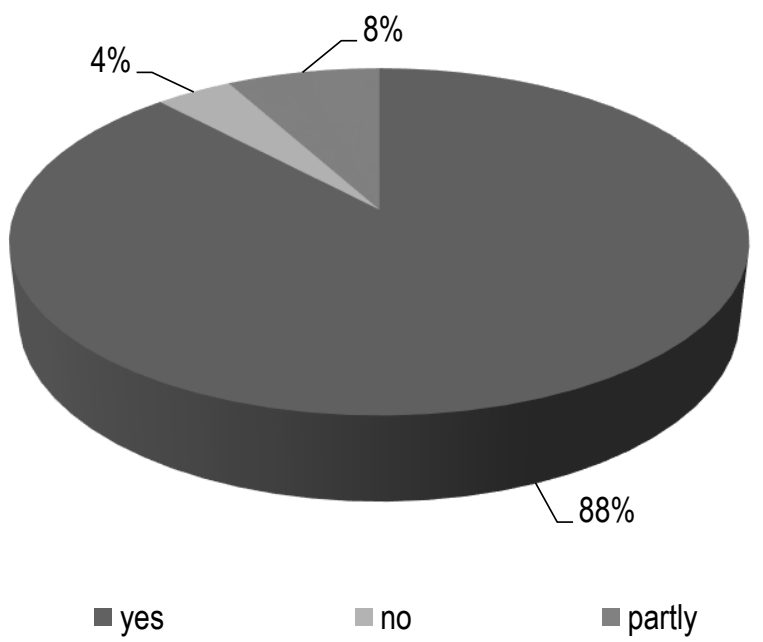

Figure 2 - Does a start-up fully accept business risk and is ready to bear its financial effects on its own? (own study based on conducted analyses)

However, we need to underline that despite full readiness to accept the entire business risk, start-ups do undertake certain risk-limiting activities. In this regard, for example, $28 \%$ of the analysed entities transfer a part of risk to suppliers (particularly financial risks), $20 \%$ of enterprises try to establish financial reserves that could be used in the face of risk materialisation and as many as $36 \%$ of entities are ready to withdraw from the task execution, if the risk was to exceed their financial ability to cover for the losses. What is noticeable is that only $8 \%$ of start-ups try to use insurance - the most popular, the most widely available and the cheapest risk transfer solution - in the risk financing process.

Step II - expert analysis using the Analytic Hierarchy Process (AHP). AHP is a multi-criterion method prepared by T. Saaty to analyse complex decision-making problems [17]. It allows ordering the decisionmaking problem through presenting it in a form of a hierarchical structure and assigning weights to particular criteria on the basis of comparisons of pairs. This method combines subjective expert opinions with an objective mathematical analysis of decisions obtained through surveys that concern partial relationships and links between factors that describe an analysed problem.

One of the main tasks of the Analytic Hierarchy Process is to conduct a quantitative assessment of non-material phenomena. Modelling through the use of AHP is used especially when clear-cut functional relationships between elements of an analysed problem are unknown, but the problem can be described through a hierarchical structure of criteria and is estimable owing to the presence of characteristic features. In order to conduct a quantitative assessment of issues usually presented in qualitative terms, the method uses pairwise comparisons of decision-making variants, utilizing a specially crafted scale of grades that expresses domination of particular elements. The so-called fundamental, 9-step scale of comparisons developed by $T$. Saaty is used in the process of comparing [17]. It can be applied when analysing both quantitative and qualitative variables. Each pair $(i, j)$ of examined factors is assigned a measure of importance and the obtained results are introduced to the $V$ matrix that presents a preference of one factor over the other [18] (1): 


$$
V=\left[V_{i} / V_{j}\right]=\left[\begin{array}{cllc}
v_{1} / v_{1} & v_{1} / v_{2} & \ldots & v_{1} / v_{n} \\
v_{2} / v_{1} & v_{2} / v_{2} & \ldots & v_{2} / v_{n} \\
\ldots & \ldots & \ldots & \ldots \\
v_{n} / v_{1} & v_{n} / v_{2} & \ldots & v_{n} / v_{n}
\end{array}\right]
$$

Four principles that condition the validity of comparisons within the AHP structure are applied [19]:

- pairwise comparisons of each element with one another;

- according to the "bottom-up" principle;

- in relation to an element located one level up in the hierarchy;

- according to the reciprocity of assessments rule.

In order for a structure to be analysed in a correct way, elements must be compared with one another within every single structure. This means that pairwise comparison matrices are built for elements located on each level of the hierarchical structure.

Due to the fact that the article aims at presenting research results and specialist software was used in data processing (Super Decisions), the study omits descriptions and mathematical formulae that refer to the conducted analysis in particular stages. The presentation includes final results of calculations. However, we need to emphasize that results of an analysis of a hierarchical structure can be deemed reliable, if for each analysed matrix the principle of conformity of assessments has been observed, where $\mathrm{CR} \leq 0.1$ (Consistency Ratio) determines the degree to which the comparisons of validity of characteristics do not conform with one another [20]. This ratio has been elaborated on the basis of formula (2):

$$
C R=\frac{C I}{R I}
$$

where $R l$ is a random index of non-conformity, whose level has been estimated by T. Saaty [16].

The study takes account of the most important - according to participant experts - sources of start-up risk financing that include: a banking credit, a supplier credit, a client credit, Venture Capital, Business Angels and insurance. The criteria taken into consideration when analysing the price include financing cost, availability of funds, waiting time, restrictions concerning their use for corporate purposes and volume of funds. The results are presented in Table 1 below.

Table 1 - Selection of an optimal start-up risk financing method (own calculations supported by Super Decisions software)

\begin{tabular}{|l|c|c|c|c|c|c|}
\hline \multicolumn{1}{|c|}{ Parameter } & Cost & Availability & Waiting time & $\begin{array}{c}\text { Restrictions } \\
\text { of use }\end{array}$ & $\begin{array}{c}\text { Volume } \\
\text { of funds }\end{array}$ & Ratio \\
\hline Banking credit & 0,0161 & 0,0277 & 0,0361 & 0,0450 & 0,0224 & 0,1473 \\
\hline Supplier credit & 0,0420 & 0,0256 & 0,0250 & 0,0248 & 0,0207 & 0,1380 \\
\hline Client credit & 0,0695 & 0,0258 & 0,0174 & 0,0154 & 0,0088 & 0,1368 \\
\hline Venture Capital & 0,0110 & 0,0074 & 0,0083 & 0,0163 & 0,0217 & 0,0647 \\
\hline Business Angels & 0,0296 & 0,0104 & 0,0120 & 0,0229 & 0,0393 & 0,1142 \\
\hline Insurance & 0,1292 & 0,0715 & 0,0694 & 0,0734 & 0,0554 & 0,3990 \\
\hline
\end{tabular}

The conformity ratio of the conducted hierarchical structure analysis amounts to 0.9 , which means that the obtained results can be deemed reliable and the conducted analyses are valid.

As indicated by the conducted calculations based on the opinions of participant experts, insurance is the most attractive start-up risk financing instrument (which demonstrates that the $\mathrm{H} 3$ research hypothesis 
had been positively verified) - Figure 3 .

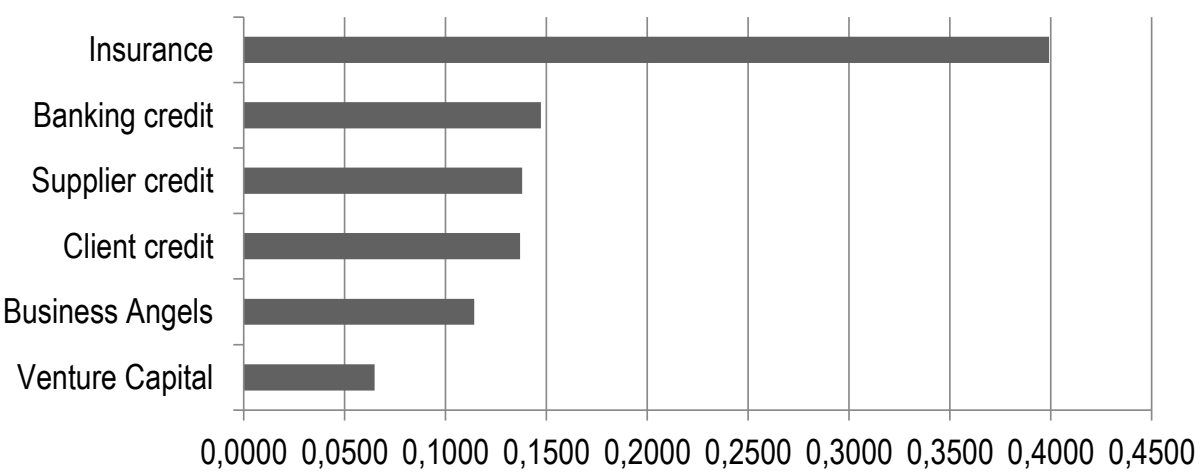

Figure 3 - Attractiveness of start-up risk financing methods (own calculations supported by Super Decisions software)

The most important factor in the assessment of attractiveness is the cost (ratio of 0.2976 ), followed by limited use (0.1977) and volume of funds, their availability and waiting time (all at 0.1683 ). The abovementioned factors presented by experts participating in the study are of key importance for safeguarding optimal conditions and operating continuity by start-ups. It is particularly important in a situation where such entities focus on maintaining their adopted development objective and an acceptable level of business risk.

Conclusions from research. Dynamic development of start-ups observed in recent years is a chance to enhance innovation of the economy and a chance for these innovative enterprises to enter European and global markets. However, their unique character results in the fact that only a small number of them become mature enterprises that enjoy market success. They are burdened by the high business risk that is volatile over time and dependent on a development stage, which determines their survival and market success rates. Therefore, the identification of business risks and the use of risk financing instruments that are available on the market represent important aspects of the start-up operation.

The research results presented above indicate that insurance should be broadly used by start-ups as a business risk financing instrument. Insurance is particularly attractive due to a relatively low cost compared to other instruments and is widely available, uncomplicated and very diverse, which allows customizing the insurance cover, taking account of needs of an individual start-up. Unfortunately, despite awareness of risks, a relatively large number of such enterprises fail to utilise insurance in their everyday operations. Certainly, there are numerous reasons behind this and they must be related to the specificity of the start-up activity. An important factor is the lack of funds since as declared by the surveyed parties, the initial stage of development forces them to invest all the funds they have in stock in further development. Regrettably, the research also shows low awareness of the possibilities of using risk management methods and applying risk financing instruments.

However, when selecting insurance products to protect the start-up activity, it must be emphasized that there is no single product or a group of products that would protect corporate assets, future profits and the company from a potential client or contractor claims. Nor is there a product to cover other aspects of the operation in a comprehensive manner and a one that would additionally be appropriate for every enterprise. This could lead to a situation where in spite of having bought an insurance policy, a start-up will not be protected from potential hazards. Therefore, each start-up should adjust the insurance coverage to individual needs. Although the market does not offer products dedicated to this group of high-risk 
entities, a broad spectrum of protective products offered by insurers result in a possibility of granting protection in a manner that is tailored to individual needs of start-ups. This is particularly important given the operational risk volatility, whereas the use of an optimal insurance coverage of the business activity can certainly become one of the preconditions of market success achieved by this type of enterprises.

1. Sowiński, R. (2012). W czym tkwi siła amerykańskich start-upów. Warszawa: Polska Agencja Rozwoju Przedsiębiorczości (PARP).

2. Willet, A. H. The Economic Theory of Risk and Insurance (New York, 1901)(ii) Knight. FH, Risk, Uncertainty and Profit (New York, 1921)(iii) Hardy, CO, Risk and Risk-Bearing (Chicago, 1923)(iv) Oberparleiter, K., Funktionen und risikenlehre des warenhandels (Frankfurt, 1930).

3. Knight, F. H. (1921). Risk, uncertainty and profit. New York: Hart, Schaffner and Marx.

4. Rowe W.D. (1997). An anatomy of Risk, John Wiley \& Sons, New York 1997.

5. Tepman L.T. (2002). Riski v Ekonomike, Unity-Dana, Moskwa 2002.

6. Jabłoński D., Ryzyko przedsiębiorstwa w pracach laureatów Nagrody Nobla, [w:] Ryzyko w działalności przedsiębiorstw. A. Fierla (red.), Oficyna Wydawnicza SGH, Warszawa 2009.

7. Waściński T., Krasiński P. (2010). Ryzyko w działalności przedsiębiorstwa - elementy systematyki i identyfikacji, [w:] Zarządzanie ryzykiem działalności organizacji. J. Monkiewicz, L. Gasiorkiewicz (red.), C.H.Beck, Warszawa 2010.

8. Kowalewski E. (1998). Ryzyko w działalności człowieka i moźliwości jego ograniczenia, [w:] T. Sangowski (red.), Ubezpieczenia gospodarcze, Warszawa 1998.

9. Hadyniak, B. (2010). Ubezpieczenie jako urządzenie finansowe [w:] Ubezpieczenia podręcznik akademicki pod red. J. Handschke i J. Monkiewicz, Poltext, Warszawa.

10. Damodaran, A. (2009). Ryzyko strategiczne: podstawy zarzadzania ryzykiem (Strategic risk: the basics of risk management). Warszawa, Wydawnictwa Akademickie i Profesjonalne, Akademia Leona Koźmińskiego. p. 258.

11. Blank, S., \& Dorf, B. (2013). Podręcznik startupu. Budowa wielkiej firmy krok po kroku. Helion.

12. Ries E. (2017). Metoda lean start-up, Wydawnictwo Helion, Gliwice.

13. Osterwalder A., Pigneur Y. (2012). Tworzenie modeli biznesowych. Podręcznik wizjonera, Wydawnictwo Onepress, Gliwice.

14. Damodaran A. (2009). Valuing Young, Start-up and Growth Companies: Estimation Issues and Valuation Challenges, Stern School of Business, New York University.

15. Sitek E. (2009). Ryzyko międzynarodowej działalności inwestycyjnej, Wydawnictwo Politechniki Czestochowskiej, Częstochowa 2009, str.29.

16. Korombel A. (2013). Apetyt na ryzyko w zarządzaniu przedsiębiorstwami, Wydawnictwo Politechniki Częstochowskiej, Czestochowa 2013.

17. Saaty, T. L. (1990). How to make a decision: the analytic hierarchy process. European journal of operational research, 48(1), 9-26.

18. Alonso, J. A., \& Lamata, M. T. (2006). Consistency in the analytic hierarchy process: a new approach. International journal of uncertainty, fuzziness and knowledge-based systems, 14(04), 445-459.

19. Stefanów, P., \& Prusak, A. (2011). Badanie wiarygodności i skuteczności skali porównań Saaty'ego w metodach AHP i ANP. Przedsiębiorcze aspekty rozwoju organizacji i biznesu, pp. 271-298.

20. Downarowicz, O., Krause, J., Sikorski, M., \& Stachowski, W. (2000). Zastosowanie metody AHP do oceny i sterowania poziomem bezpieczeństwa złożonego obiektu technicznego. Wybrane metody ergonomii i nauki o eksploatacji. Gdańsk, Wydaw. Politechniki Gdańskiej, 7-42.

P. Пукала, Ph.D., Державна Вища техніко-економічна школа в м. Ярославі (Ярослав, Польща);

€. Cipe, Ph.D., Прешовський університет (Прешов, Словаччина);

P. Ваврек, Ph.D., Прешовський університет (Прешов, Словаччина).

Ризик-менеджмент та фінансування старт-ап проектів

Метою даної статті $є$ аналіз методів управління ризиками старт-ап проектів, а також фінансових інструментів зменшення цих ризиків. Автори наголошують, що специфіка реалізації та функціонування старт-ап проектів, брак статистичної інформації обумовлює необхідність застосування сучасних методів аналізу. Окрім цього відсутність накопиченої історії функціонування старт-ап проектів та статистики їх успішності обумовлює незначну кількість науково обгрунтованих публікацій за даною тематикою. 3 іншого боку, з кожним роком кількість старт-ап проектів зростає не тільки на національному, але й на міжнародному рівні, що підтверджує актуальність дослідження даної тематики. У статті проаналізовано сучасні та традиційні інструменти управління ризиками страт-ап проектів та шляхи їх мінімізації за рахунок використання фонансових інструментів. У рамках дослідження автори використовували метод експертних оцінок шляхом проведення індивідуальних інтерв'ю. Узагальнення думки експертів було проведено з 
використанням мультикритеріального методу аналізу ієрархій (Analytic Hierarchy Process), що використовується при аналізі складних завдань при прийнятmі рішень. У ході дослідження було проаналізовано $25 \mathrm{cmapm-an} \mathrm{проектів}$ Підкарпатського науково-технологічного інкубатору (Польща). Фокус-групу експертів (10 осіб) для інтерв'ю було обрано з урахуванням специфіки функціонування стар-ап проектів. Результати емпіричного аналізу отриманих даних свідчать, що, як правило, засновники старт-ап проектів не застосовували інструменти управління ризиками у своїй діяльності, розглядаючи ризик як невід'ємну властивість інновацій, не намагаючись його мінімізувати. Авторами запропоновано використовувати страхування як найефективніший інструмент фінансування ризиків старт-ап проектів з метою їх мінімізації. У роботі стверджується, що отримані результати є підгрунтям для подальших досліджень особливостей реалізації старт-ап проектів за умови нестабільного бізнес-середовища з метою мінімізації можливих ризиків.

Ключові слова: старт-ап, ризик, управління ризиками, фінансування ризиків, страхування. 